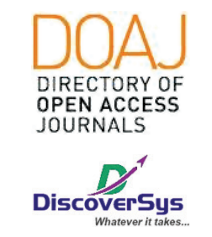

Published by DiscoverSys

\section{The characteristics of preeclampsia among patients delivered through caesarean section at Sanglah General Hospital, Denpasar, Bali in 2018}

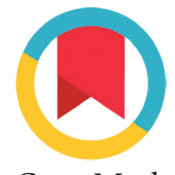

CrossMark

\author{
Anindita Pramanik,${ }^{1 *}$ Ida Bagus Gede Fajar Manuaba, ${ }^{2}$ Anak Agung Putra \\ Wiradnyana ${ }^{2}$
}

\title{
ABSTRACT
}

Background: Preeclampsia is an exclusive disorder in pregnancy characterised by hypertension as well as proteinuria and is the primary cause of mortality and morbidity of pregnant women. This study aims to determine the characteristics or risk factors in preeclampsia patients who delivered through caesarean section within the period of January $1^{\text {st }}$ to December $31^{\text {st }} 2018$ in Sanglah General Hospital Denpasar.

Methods: This study used a retrospective descriptive study design by using 34 samples of preeclampsia patients in 2018 who underwent caesarean delivery in Sanglah General Hospital Denpasar. The characteristics of these pregnant women are categorized into their age, education level, Body Mass Index (BMI), ethnicity, occupation, education level, previous history of preeclampsia, family history of preeclampsia, existing chronic hypertension, parity, number of fetus in womb, frequency of Antenatal Care (ANC), and registration method. Data were analysed by SPSS version 17 for windows.

Results: The preeclampsia sufferers were dominated by the age group of 20-35 years as many as 27 people (79.4\%). The highest body mass index is in the 1 obese group of 10 people (29.4\%). The majority of respondents were from Bali (61.8\%). Working women were predominant (67.6\%), followed by SMA education level (14.7\%), existing chronic hypertension (5.9\%), nulliparous (41.1\%), single fetuses (94.1\%), and total frequency of ANC to midwife/obstetrician consisting about $61.8 \%$.

Conclusion: It can be concluded that the majority of the patients were in the age range of 20-35 years, were Balinese and had a BMI range of Obese I. Moreover, most the preeclampsia patients in this study were working women and had an education level mostly in SMA
'Undergraduate Medical Student, Faculty of Medicine, Universitas Udayana, Bali, Indonesia ${ }^{2}$ Department of Obstetrics and Gynecologic, Faculty of Medicine, Universitas Udayana, Sanglah General Hospital, Bali, Indonesia
${ }^{*}$ Correspondence to: Anindita Pramanik; Undergraduate Medical Student, Faculty of Medicine, Universitas Udayana, Bali, Indonesia;

anin.pram@gmail.com

Keywords: characteristics, preeclampsia, caesarean section.

Cite This Article: Pramanik, A., Manuaba, I.B.G.F., Wiradnyana, A.A.P. 2019. The characteristics of preeclampsia among patients delivered through caesarean section at Sanglah General Hospital, Denpasar, Bali in 2018. Intisari Sains Medis 10(3): 659-663. D0l: 10.15562/ism.v10i3.478

\section{INTRODUCTION}

Amid pregnancy, there are a variety of complications and issues which emerge. Many pregnant women develop hypertension that is not preeclampsia; this is known as gestational high blood pressure or pregnancy-induced high blood pressure. However, with preeclampsia, you have high blood pressure, as well as protein in the urine, followed other symptoms and complications. ${ }^{1}$

More than four million women will develop preeclampsia every year. The more severe the condition of pre-eclampsia turns into, and the more prominent the danger will be, it may also be fatal. In total, pre-eclampsia and eclampsia cause $10-15 \%$ of maternal deaths. In Indonesia, severe preeclampsia ranges from $3-10 \%$ and perinatal deaths are of $30-40 \% .^{2-4}$

Preeclampsia is mainly derived from abnormal placentation where a defective invasion of the spiral arteries by cytotrophoblast cells are observed. ${ }^{3}$ Usually, it onsets at the $20^{\text {th }}$ week of pregnancy. Basically, it may be broken down into a two-stage process which shows that in stage one a poorly perfused placenta produces factors leading to stage two where the clinical manifestations of preeclampsia occur. However, Stage 1 is not enough to cause the maternal syndrome but interacts with maternal constitutional factors such as genetics, behavioural or environmental that can generate Stage $2 .^{5}$

Severe preeclampsia such as eclampsia, HELLP syndrome, stroke and fatality may occur. Before the consequences occur, the best possible way to cure preeclampsia is by delivery. ${ }^{6}$ In severe cases, a caesarean section has to be performed. Therefore, some preventions and management need to be taken into action to avoid such an occurrence. Based on those mentioned above, this study aims to know from the public for general information on preeclampsia, as well as for educational purposes on characteristics of preeclampsia patients who have had caesarean delivery in Sanglah General Hospital, Denpasar.

\section{METHODS}

This research is based on a retrospective study where past medical records of preeclampsia patients who underwent caesarean delivery were studied. These medical records were taken of the year 2018 
in Sanglah General Hospital. The subject of this research is chosen through the inclusion criteria which are the pregnant women who had been diagnosed with preeclampsia and underwent caesarean delivery in Sanglah General Hospital Denpasar within $1^{\text {st }}$ January 2018 to $31^{\text {st }}$ December 2018.

A total sampling technique is used on the secondary data of the subjects who have fulfilled the inclusion criteria. After data collection, the data was measured and categorised based on the variables of

\section{Table 1 The characteristics of preeclampsia patients who delivered through caesarean section at Sanglah General Hospital Denpasar during the study period}

\begin{tabular}{|c|c|c|}
\hline Variables & Frequency $(\mathrm{N}=34)$ & Percentage (\%) \\
\hline \multicolumn{3}{|l|}{ Age (Years) } \\
\hline$<20$ & 3 & 8.8 \\
\hline $20-35$ & 27 & 79.4 \\
\hline$>35$ & 4 & 11.7 \\
\hline \multicolumn{3}{|c|}{ Body Mass Index (BMI) } \\
\hline Underweight & 1 & 2.9 \\
\hline Normal & 9 & 26.5 \\
\hline Overweight & 9 & 26.5 \\
\hline Obese I & 10 & 29.4 \\
\hline Obese II & 5 & 14.7 \\
\hline \multicolumn{3}{|l|}{ Ethnicity } \\
\hline Bali & 21 & 61.8 \\
\hline Jawa & 5 & 14.7 \\
\hline Flores & 2 & 5.9 \\
\hline Madura & 1 & 2.9 \\
\hline Sumba & 3 & 8.8 \\
\hline Manggarai & 2 & 5.9 \\
\hline \multicolumn{3}{|l|}{ Occupation } \\
\hline Entrepreneur & 8 & 23.5 \\
\hline Private Employee & 11 & 32.4 \\
\hline Farmer & 3 & 8.8 \\
\hline Housewife & 11 & 32.4 \\
\hline Others & 1 & 2.9 \\
\hline \multicolumn{3}{|l|}{ Education level } \\
\hline SD & 5 & 14.7 \\
\hline SMP & 6 & 17.6 \\
\hline SMA & 21 & 61.8 \\
\hline Diploma/Bachelor & 2 & 5.9 \\
\hline \multicolumn{3}{|c|}{ Previous History of Preeclampsia } \\
\hline Present & 4 & 11.8 \\
\hline Absent & 30 & 88.2 \\
\hline \multicolumn{3}{|c|}{ Family History of Preeclampsia } \\
\hline Present & 3 & 8.8 \\
\hline Absent & 31 & 91.2 \\
\hline
\end{tabular}

this research. Once the data had been classified into its respective variables, it was then processed and analysed. Then, the data was portrayed descriptively in a table form to be interpreted.

The variables of this research are characteristics of pregnant women with preeclampsia who underwent caesarean delivery. The characteristics of these pregnant women are categorized into their age, education level, Body Mass Index (BMI), ethnicity, occupation, education level, previous history of preeclampsia, family history of preeclampsia, existing chronic hypertension, parity, number of fetus in womb, frequency of Antenatal Care (ANC), and registration method. Data were analysed by SPSS version 17 for Windows.

\section{RESULTS}

Based on the registration data of Sanglah Hospital Medical Record Installation, Denpasar, from January 1st to December $31^{\text {st }} 2018,34$ medical records have passed the inclusion criteria of this study. The characteristics of these samples consist of age, education level, Body Mass Index (BMI), ethnicity, occupation, education level, previous history of preeclampsia, family history of preeclampsia, existing chronic hypertension, parity, number of fetus in womb, frequency of Antenatal Care (ANC), and registration method.

Table 1 shows that the age of the subjects is dominated by the age group 20-35 years by $27(79.4 \%)$ out of 34 samples. A total of 4 patients $(11.7 \%)$ are of age group $>35$ years and 3 patients $(8.8 \%)$ from age group $<20$ years. In addition, BMI is lowest at underweight which is 1 person $(2.9 \%)$. 9 people (26.5\%) are standard and another 9 people $(26.5 \%)$ overweight while 5 people $(14.7 \%)$ are Obese II. It is found in this study that pregnant women with preeclampsia are highest in Obese I which is BMI $25-29.9 \mathrm{~kg} / \mathrm{m}^{2}$ consisting of 10 people (29.4\%). When Obese I and II are combined as a whole, 15 people $(44.1 \%)$ out of the sample size have obesity (Table 1). Based on ethnicity, they are dominated by Bali with 21 people (61.8\%). After Bali, the second-highest ethnicity comes from Jawa with 5 people $(14.7 \%)$. The next ethnicity comes from Sumba with 3 people $(8.8 \%)$, followed by 2 people (5.9\%) from Flores and 2 people (5.9\%) from Manggarai. Lastly, 1 person (2.9\%) is Madura (Table 1).

Based on the occupation, 8 people (23.5\%) are entrepreneurs, 11 people $(32.4 \%)$ are private employees, 3 people $(8.8 \%)$ are farmers, followed 11 people $(32.4 \%)$ who are housewives and 1 person (2.9\%) under others. The total percentage of working women is $67.6 \%$ by adding the percentages of entrepreneur, private employee, farmer and others, 
Table 2 The characteristics of preeclampsia based on several variables Sanglah General Hospital Denpasar during the study period who underwent caesarian section.

\begin{tabular}{lcc}
\hline Variables & Frequency $(\mathbf{N}=\mathbf{3 4})$ & Percentage (\%) \\
\hline Existing Chronic Hypertension & 2 & 5.9 \\
$\quad$ Present & 32 & 94.1 \\
$\quad$ Absent & & \\
Parity & 14 & 41.1 \\
$\quad$ Nulliparous & 9 & 26.5 \\
$\quad$ Primiparous & 11 & 32.4 \\
$\quad$ Multiparous & & \\
Number of Fetuses & 32 & 94.1 \\
$\quad$ Singleton & 2 & 5.9 \\
Twins & & \\
Frequency and Location of ANC & 13 & 38.2 \\
$\quad<3$ times with midwife/ obstetrician & 21 & 61.8 \\
$\quad 3$ times with midwife/ obstetrician & & \\
Registration Method & 31 & 91.2 \\
General & 2 & 2.9 \\
BPJS & 1 & \\
JAMPERSAL & & \\
\hline
\end{tabular}

while $32.4 \%$ of housewife percentage is non-working women. Besides, according to education level, it is found that SMA is highest with 21 people (14.7\%) followed by SMP which are 6 people (17.6\%) then SD with 5 people (14.7\%) and the least is diploma/ bachelor consisting of 2 people (5.9\%) (Table 1$)$. In Table 1, it is found that only 4 people (11.8\%) have had preeclampsia in their previous pregnancies, whereas 30 people (88.9\%) did not have past preeclampsia. Whereas, the recent findings also found that 3 people $(8.8 \%)$ have had family members with preeclampsia while 31 people $(91.2 \%)$ did not have a family history of preeclampsia (Table 1 ).

Based on Table 2, it is found that 2 people (5.9\%) had existing chronic hypertension, whereas 32 people $(94.1 \%)$ did not have existing chronic hypertension. In pregnancy, American College of Obstetrics and Gynecology (ACOG) defines chronic hypertension as blood pressure $\geq 140 \mathrm{~mm}$ $\mathrm{Hg}$ systolic in recognition that many women seek medical care before 20 weeks of gestation (Table 2).

The parity is highest in nulliparous by 14 people $(41.1 \%)$, followed by multiparous, which are 11 people $(32.4 \%)$ and the least is primiparous which are 9 people $(26.5 \%)$. Based on Table 2, 32 people $(94,1 \%)$ have had single fetuses in their womb while only 2 people $(5,9 \%)$ had twins. A minority of 13 people $(38.2 \%)$ had visits lesser than 3 times with midwife or obstetrician while majority had 3 visits or more which consists of 21 people $(61.8 \%)$. The registration method is highest with
31 people $(91.2 \%)$ at general patients, followed by BPJS which includes of 2 people (5.8\%) and 1 person (2.9\%) under JAMPERSAL (Table 2)

\section{DISCUSSION}

The results of this study show that a majority of the preeclampsia patients were Balinese. This may be the reason due to Sanglah General Hospital being positioned in Denpasar, Bali. Moreover, a majority of the preeclampsia patients in this study were aged between 20-35 years. This is similar to the research carried out by Adjie where among 183 cases of preeclampsia with severe features, it was found that 124 people $(67.76 \%)$ were aged between 20-35 years, while 49 people $(26.78 \%)$ were aged $>35$ years. $^{7}$ This states that preeclampsia is more dominant is pregnant women aged 20-35 years. However, an extreme maternal age of fewer than 20 years or more than 35 years increases the risks of developing preeclampsia. ${ }^{8}$

About $44 \%$ of the preeclampsia patients were obese, while another $26.5 \%$ were overweight. According to a study by Bodnar, it was found that pregnant obese women had preeclampsia odds ratio of two to three folds more than non-obese pregnant women.' Another research done by Kartasurya compared overweight pregnant women with lean pregnant women and found that out of a 200 sample total, overweight women had an odds ratio of 4.6 times more to have preeclampsia than lean women. ${ }^{10}$ Therefore, the risk of preeclampsia increases progressively with increasing BMI. ${ }^{11}$

In this research, it was found that a majority of the preeclampsia patients were working women. A study by Fransiska showed that severe physical activity would increase the risk of preeclampsia in a pregnant woman compared to low physical activity, but there was no significant difference in pregnant women with moderate physical activity. ${ }^{12} \mathrm{~A}$ working woman can be classified with a high physical activity compared to non-working women. According to Klonoff-Cohen, working women had the risk of developing preeclampsia 2.3 more compared to nonworking women. ${ }^{13}$ There is an increased risk of preeclampsia for women with high-stress jobs which come with high psychological demand. Be it a working woman or not, any kind of mental stress due to uneasy environment of office or home could result in biological changes in pregnant women which may lead to preeclampsia. ${ }^{14}$

Most of the preeclampsia patients in this study had an education level highest in SMA, which is high school. According to Silva, women with low education is found to have a higher risk of developing preeclampsia as much as 5.1 times more than highly educated women. ${ }^{15}$ This is due to the 
correlation between the level of maternal education with the use of health services. Women with a low education background would not be as competent in the ability to obtain and comprehend health information such as ANC, signs of complications and ideal maternal nutrition as thoroughly as a woman with high education. ${ }^{16}$

World Health Organisation (WHO) states that ANC is provided by skilled health-care professionals to pregnant women to ensure the best health conditions and safety for both mother and baby during pregnancy. ANC will be able to help reduce maternal and perinatal morbidity and mortality by early detection and treatment of pregnancy-related complications. Although the data in the table above shows that the majority of the women had undergone ANC for more than 3 times, a lot of other factors can relate to the occurrence of preeclampsia. In this research, 24 women have had an education of SMA level or higher. This may be a cause of the ANC frequency to be higher among most of the patients.

The data found in this study shows that the majority did not have previous history of preeclampsia. Research by Hjartardottir showed that the estimated recurrence of preeclampsia in a second pregnancy was $13 \%{ }^{17}$ There is only a $7-20 \%$ chance of preeclampsia recurrence in the woman's subsequent pregnancy. ${ }^{11}$ Research by Duckitt states that a pregnant woman with family history of preeclampsia has 3 times the risk of developing preeclampsia. ${ }^{18}$ However, the data found in this research is different due to a smaller sample size because in this research only 3 out of 34 samples had family history of preeclampsia. Only $5.9 \%$ of the preeclampsia patients in this research had existing chronic hypertension. According to a research by Catov, chronic hypertension could increase the risk of developing severe preeclampsia up to $16.7 \%$ for women with first-time pregnancies. ${ }^{19}$ However, in a study by Kashanian based on sample size of 318 cases of pregnant women with preeclampsia; it was found that 305 of them did not have pre-existing hypertension. ${ }^{20}$

Preeclampsia is often experienced more by nulliparous women as compared to multiparous. ${ }^{21}$ The data found in this study is similar to one of Opitasari's where the research showed that nulliparous women have $78 \%$ higher risks of developing preeclampsia than primiparous women. ${ }^{16}$ Another study by Lee found that nulliparous women have an OR of 1.3 times for preeclampsia. ${ }^{14} \mathrm{~A}$ majority of the preeclampsia patients in this study bore singletons in their wombs rather than twins. However, research by Francisco suggests that women bearing twins have higher chances of developing preeclampsia than those carrying singletons. ${ }^{22}$ This difference may be due to a smaller sample size of this research.

\section{CONCLUSION}

In this research-based on characteristics of preeclampsia patients who delivered through caesarean section within the period of $1^{\text {st }}$ January 2018 to $31^{\text {st }}$ December 2018, it can be concluded that the majority of the patients were in the age range of 20-35 years, were Balinese and had a BMI range of Obese I. Moreover, most preeclampsia patients in this study were working women and had an education level, mostly in SMA. Previous and family history of preeclampsia was significantly low among these preeclampsia patients. Existing chronic hypertension too was dominantly absent among them. Most of these preeclampsia patients were nulliparous, and a majority bore single fetuses in their womb. The frequency of ANC was highest in 3 or more visits with midwife or obstetrician, and most of these preeclampsia patients were general patients.

\section{ETHICAL CONSIDERATION}

Ethics consideration has been obtained from the Ethics Committee, Faculty of Medicine, Universitas Udayana, Bali, Indonesia prior to the study being conducted

\section{CONFLICT OF INTEREST}

None

\section{FUNDING}

The authors are responsible for the funding of study without the involvement of grant, sponsorship, or any other resources of funding.

\section{AUTHORS CONTRIBUTION}

All of the authors are equally contributed to the study from the conceptual framework, data gathering, data analysis, until reporting the results of study.

\section{REFERENCE}

1. English FA, Kenny LC, McCarthy FP. Risk factors and effective management of preeclampsia. Integr Blood Press Control. 2015;8:7-12.

2. Lyall F, Belfort M. Pre-eclampsia: Etiology and Clinical Practice. Cambridge: Cambridge University Press. 2007.

3. Uzan J, Carbonnel M, Piconne O, Asmar R, Ayoubi JM. Pre-eclampsia: pathophysiology, diagnosis, and management. Vasc Health Risk Manag. 2011;7:467-74.

4. Astuti LD, Sunaryo T, Haryati SD. Risk factors analysis of preeclampsia weight loss in third trimester pregnant women. Journal of Integrated Health Sciences. 2013;2(2).

5. Roberts JM, Hubel CA. The two stage model of preeclampsia: variations on the theme. Placenta.2008;30 Suppl A:S32-S37. 
6. Duley L. Pre-eclampsia and the hypertensive disorders of pregnancy. Br Med Bull. 2003;67:161-76.

7. Adjie JMS, Lisnan F, Sutandar Y. The characteristics of preeclampsia with severe features. Indonesian Journal of Obstetrics and Gynecology. 2016;4(4):179-182.

8. Chaiworapongsa T, Chaemsaithong P, Yeo L, Romero R. Pre-eclampsia part 1: current understanding of its pathophysiology. Nat Rev Nephrol. 2014;10(8):466-80. 9.

9. Bodnar LM, Ness RB, Markovic N, et al. The risk of preeclampsia rises with increasing prepregnancy body mass index. Ann Epidemiol. 2005;15(7):475-482.

10. Kartasurya M. Pre-eclampsia Risk Factors of Pregnant women in Semarang, Indonesia. IJSBAR. 2015;22(1):31-37.

11. Jeyabalan A. Epidemiology of preeclampsia: impact of obesity. Nutr Rev. 2013;71 Suppl 1:S18- S25.

12. Fransiska L, Patmini E, Wahab A, Emilia O. Pendidikan/ Pekerjaan Maternal dan factor resiko preeclampsia: Studi Epidemiologi di kota Ternate. Jurnal Kesehatan Reproduksi. 2014;1(3):175-183

13. Klonoff-Cohen HS, Cross JL, Pieper CF. Job stress and preeclampsia. Epidemiology. 1996;7(3):245-249.

14. Lee CJ, Hsieh TT, Chiu TH, Chen KC, Lo LM, Hung TH. Risk factors for pre-eclampsia in an Asian population. Int J Gynaecol Obstet 2000;70(3):327-333.

15. Silva LM, Coolman M, Steegers EA, et al. Low Socioeconomic status is a risk factor for preeclampsia: The generation R Study. J Hypertens. 2008;26(6):1200-8.

16. Opitasari C, Andayasari L. Parity, education level and risk for pre-eclampsia in selected hospitals in Jakarta. Health Science Journal of Indonesia. 2014;5(1):35-39
17. Hjartardottir $\mathrm{S}$, Leifsson BG, Geirsson RT, Steinthorsdottir V. Recurrence of hypertensive disorder in second pregnancy. Am J Obstet Gynecol. 2006; 194(4):916-920.

18. Duckitt K, Harrington D. Risk factors for pre-eclampsia at antenatal booking: systematic review of controlled studies. BMJ. 2005;330(7491):565-567

19. Catov JM, Ness RB, Kip KE, Olsen J. Risk of early or severe pre-eclampsia related to pre-existing conditions. Int $\mathrm{J}$ Epidemiol. 2007; 36(2):412-419.

20. Kashanian $M$, Baradaran HR, Bahasadri S, Alimohammadi R. Risk factors for pre-eclampsia: a study in Tehran, Iran. Arch Iran Med. 2011;14(6):412-415.

21. Cunningham FG, Leveno KJ, Bloom SL et al. Hypertensive disorders. William Obstetrics. 24th edition; McGraw Hill Education. 2014:761-808.

22. Francisco C, Wright D, Benkő Z, Syngelaki A, Nicolaides KH. Competing risks model in screening for pre eclampsia in twin pregnancy by maternal characteristics and medical history. Ultrasound Obstet Gynecol. 2017;50(4):501-506

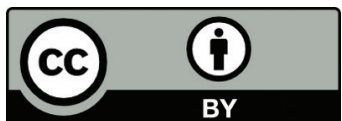

This work is licensed under a Creative Commons Attribution 